\title{
Impact of riparian land-use patterns on Ephemeroptera community structure in river basins of the southern Western Ghats, India
}

\author{
C. Selvakumar ${ }^{(1), \star}$, K.G. Sivaramakrishnan ${ }^{(2)}$, S. Janarthanan ${ }^{(1)}$, \\ M. Arumugam ${ }^{(1)}$, M. Arunachalam ${ }^{(3)}$
}

Received September 9, 2013

Revised December 13, 2013

Accepted December 16, 2013

Key-words: Ephemeroptera, riparian land use, bioindicators, KMTR, Western Ghats

\section{ABSTRACT}

This study analysed the impact of riparian land use in structuring the lar$\mathrm{val}$ ephemeropteran communities from 25 sites in streams and rivers of Kalakad-Mundanthurai Tiger Reserve (KMTR) of the southern end of the Western Ghats, India. A total of twenty-eight species belonging to twentyfour genera of six families were collected across all the sites. Baetidae and Leptophlebiidae were the most numerous and ubiquitous families, comprising eight genera in each family and eleven and nine species, respectively. The physico-chemical parameters and species richness and abundance of mayflies varied across streams and rivers with different riparian land-use types. Species distribution was influenced by the environmental gradients. Canonical Correspondence Analysis revealed a clear separation of the mayfly assemblages along water quality and riparian landuse gradients. The results of this study suggest that Ephemeroptera taxa can be potentially used as sensitive indicators of riparian land use in lotic ecosystems.

\section{RÉSUMÉ}

Impact des modes d'utilisation des terres riveraines sur la structure de la communauté d'éphéméroptères dans les bassins hydrographiques des Ghâts occidentaux du sud, Inde
Mots-clés :
Cette étude a analysé l'impact de l'utilisation des terres riveraines dans la struc- Ephéméroptère, utilisation
des terres riveraines, bioindicateurs, KMTR, Ghâts occidentaux turation des communautés de larves d'éphéméroptères de 25 sites dans les
ruisseaux et les rivières de la Kalakad-Mundanthurai Tiger Reserve (KMTR) de
l'extrémité sud des Ghâts occidentaux, en Inde. Un total de vingt-huit espèces
appartenant à vingt-quatre genres de six familles a été collecté sur l'ensemble des
sites. Baetidae et Leptophlebiidae étaient les familles les plus nombreuses et om-
niprésentes, comprenant huit genres dans chaque famille et onze et neuf espèces,
respectivement. Les paramètres physico-chimiques et la richesse en espèces et
l'abondance des éphémères variaient entre ruisseaux et rivières de différents types
d'utilisation des terres riveraines. La distribution des espèces est influencée par les
gradients environnementaux. L'analyse canonique des correspondances a révélé

(1) Department of Zoology, University of Madras, Guindy Campus, Chennai-600025, India

(2) Department of Zoology, Madras Christian College (Autonomous), Tambaram East, Chennai-600 059, India

(3) Sri Paramakalyani Centre for Environmental Sciences, Manonmaniam Sundaranar University, Alwarkurichi627412, Tamilnadu, India

* Corresponding author: selvaaa06@gmail.com 
une nette séparation des assemblages d'éphémères le long du gradient de qualité de l'eau et d'utilisation des terres riveraines. Les résultats de cette étude suggèrent que les taxons d'Ephéméroptères peuvent être potentiellement utilisés comme indicateurs sensibles à l'utilisation des terres riveraines dans les écosystèmes lotiques.

\section{INTRODUCTION}

Around the world, freshwater habitats are being subjected to increased levels of human disturbance (Saunders et al., 2002). A global assessment of the status of inland water ecosystems shows that most threatened river catchments are to be found in the Indian subcontinent (Groombridge and Jenkis, 2000). Dudgeon (1994; 2000) stressed the importance of biomonitoring and identifying areas of riverine biodiversity for long-term conservation. Biological assessment of the freshwater habitats aims to characterise and monitor the conditions of the aquatic resources (Sivaramakrishnan et al., 1996). The assessments are commonly associated with human impacts (Resh et al., 1995). The use of living organisms for monitoring water quality originated in Europe and it is widely used in developed and developing countries (Cairns and Pratt, 1993; Metcalfe-Smith, 1994; Bonada et al., 2006). A spectrum of biological communities including plankton, periphyton, microphytobenthos, macrozoobenthos, aquatic macrophytes and fishes have been used in the assessment of river water quality (De Pauw et al., 1992; Bae et al., 2005; Li et al., 2010).

The systematic development and testing of rapid bioassessment tools on river basins using benthic macroinvertebrates in developing countries like India (Sivaramakrishnan et al., 1996; Sivaramakrishnan, 2000; Subramananian et al., 2005; Dinakaran and Anbalagan, 2007a; 2007b; Sharma et al., 2008; Muralidharan et al., 2010), Thailand (Boomsoong et al., 2008; 2009), Malaysia (Ahmad et al., 2002) and Brazil (Callisto et al., 1998; Buss, 2001; Buss et al., 2002; Silveira et al., 2005; Buss and Salles, 2007) are quite recent. However, due to limited knowledge of the taxonomy and distribution of macroinvertebrates in these countries, these studies have mostly been confined to supraspecific taxonomic levels. Many monitoring programs utilise the EPT (Ephemeroptera, Plecoptera, Trichoptera) index, which is widely used for monitoring efforts.

Several studies in the past revealed that mayfly community structure successfully reflected the environmental conditions in terms of water quality and habitat selection (Gupta and Michael, 1992; Bauernfeind and Moog, 2000; Medina and Vallania, 2001; Ogbogu and Akinya, 2001; Baptista et al., 2001; Rueda et al., 2002; Nelson and Roline, 2003; Buss and Salles, 2007; Arimoro and Muller, 2009; Pond, 2010; Savić et al., 2010; 2011; Kumar et al., 2012) and mayflies are widely used for monitoring efforts. As such, the importance of mayfly communities as biological indicators of organic pollution in the riverine basins of the KMTR was evaluated and the impact of riparian land use in structuring larval ephemeropteran communities was assessed.

\section{MATERIALS AND METHODS}

\section{$>$ STUDY AREA}

Kalakad-Mundanthurai Tiger Reserve (KMTR), a valuable repository of biodiversity, is in the southern end of the Western Ghats, India, in the Ashambu hills of the Agasthiamalai region (Figure 1). The KMTR, at about $841 \mathrm{~km}^{2}$, comprises a cluster of Protected Areas and Managed Forests on both sides of the interstate border of Kerala and Tamil Nadu and attracts international conservation efforts. The reserve is located between latitude $8^{\circ} 25^{\prime}$ and $8^{\circ} 53^{\prime} \mathrm{N}$ 


\section{KALAKKAD - MUNDANTHURAI TIGER RESERVE (KMTR)}

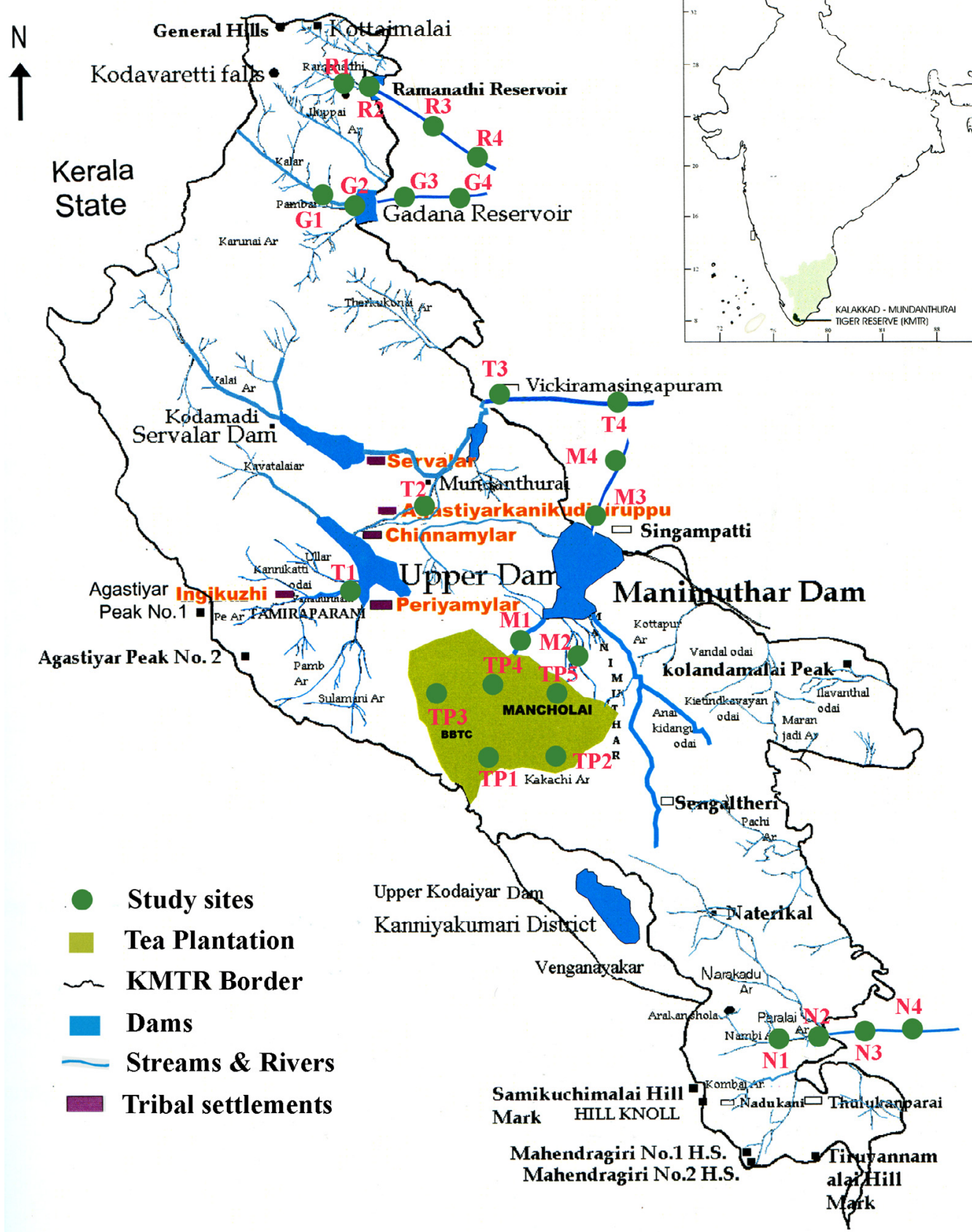

Figure 1

Map of the study area showing location of the sampling sites in KMTR. 
and longitude $77^{\circ} 10^{\prime}$ and $77^{\circ} 35^{\prime} \mathrm{E}$. The reserve spans a range of 40 to $1800 \mathrm{~m}$ in elevation. Agasthiyamalai $(1681 \mathrm{~m})$ is in the core zone of the reserve. The Western part of the KMTR, especially along the crest, receives between 2000 and $5000 \mathrm{~mm}$ of rainfall during the summer monsoon (south-west monsoon), and has a 2- to 3-month dry period. After crossing the crest of the Ghats, rainfall diminishes abruptly to $1200-2000 \mathrm{~mm}$ and at the foot of the Ghats it is between $900-1200 \mathrm{~mm}$. The temperature remains higher than $23^{\circ} \mathrm{C}$ along the eastern slope, below $900 \mathrm{~m}$ and varies between 16 and $23{ }^{\circ} \mathrm{C}$ above $900 \mathrm{~m}$. It is more than $15{ }^{\circ} \mathrm{C}$ below $1450 \mathrm{~m}$ and less than $15^{\circ} \mathrm{C}$ above $1450 \mathrm{~m}$. KMTR has vegetation types ranging from thorn scrub to montane (wet) evergreen forests, all within an altitudinal range from sea level to1866 $\mathrm{m}$ above sea level (Johnsingh, 2001). It gives rise to as many as 14 rivers and there are eleven dams in and around KMTR catering to the agricultural and drinking water needs of the 3 districts.

The headwaters of the KMTR have been protected and there is minimal human impact on these riverine systems. However, the human population has increased in the last two decades. Unsustainable agricultural activities, in particular stream bank cultivation, coupled with the catchment's high slope factor, have increased sedimentation, and there is clear evidence of structural degradation in many watercourses draining the human-inhabited areas. Located on top of the Manimuthar dam and the Manimuthar water falls, the Manjolai area comprises tea plantations established by the British during the colonial era with small settlements around them. However, the KMTR streams/rivers are still reasonably unimpacted because of the aforementioned protection.

From the KMTR catchment, 25 sites were selected to cover a disturbance gradient from intact forested sites in protected areas to degraded sites in downstream areas. The rivers sampled in this study area are Ramanathi, Gadana, Tamiraparani, Manimuthar and Nambiyar. Each site was placed into one of the three land-use categories: native forest, tea plantation and agriculturally impacted (Table I).

\section{> SAMPLE COLLECTION}

A total of 25 sites were sampled on three occasions: July (2011), December (2011) and May (2012) for aquatic insects in ten reference sites, five tea plantation sites and tenagriculturallyimpacted sites from streams/rivers of the KMTR sanctuary. Standard kicknet methodology with triplicate sampling was followed (Burton and Sivaramakrishnan, 1993). Co-occurring habitat and physico-chemical measurements (air temperature, water temperature, $\mathrm{pH}$, conductivity and dissolved oxygen) were recorded for each sampling site. Water samples were collected from each site at the time of sampling and brought to the laboratory. Water samples were analysed for other parameters such as alkalinity, hardness, biological oxygen demand, chemical oxygen demand, total solids, total dissolved solids and total suspended solids (APHA, 1998). All insects were preserved in $80 \%$ ethyl alcohol. Mayfly larvae are particularly fragile because the gills and terminal filaments detach from the body very easily. To minimise damage to specimens, mayflies were collected in containers separate from other aquatic insects. Collected samples were brought to the laboratory and were examined under microscopes (Zeiss, Stemi DV4 and Olympus MIC-D), and identified using standard taxonomic literature.

\section{> DATA ANALYSIS}

The structure of the Ephemeroptera assemblage was evaluated by species richness and abundance. The physico-chemical and mean abundance values were transformed into log values. Canonical Correspondence Analysis (CCA) was performed to determine relationships between environmental variables and respective biotic components. CCA was performed by the PAST (1.89) freeware package (Hammer et al., 2001). 
Table I

Land use and co-occurring habitat parameters of reference, tea plantation and agricultural impact sites of streams and rivers of KMTR.

\begin{tabular}{|c|c|c|c|c|}
\hline $\begin{array}{l}\text { River } \\
\text { name }\end{array}$ & $\begin{array}{l}\text { Site } \\
\text { code }\end{array}$ & $\begin{array}{l}\text { Altitude } \\
(\mathrm{m})\end{array}$ & $\begin{array}{l}\text { Land } \\
\text { use }\end{array}$ & $\begin{array}{l}\text { Co-occurring } \\
\text { habitat parameters }\end{array}$ \\
\hline \multirow[t]{4}{*}{ Ramanathi } & R1 & 237 & Native forest & Bedrock, boulders, cobble, gravel, sand \\
\hline & $\mathrm{R} 2$ & 224 & Native forest & Bedrock, boulders, cobble, gravel, sand \\
\hline & R3 & 109 & Agriculture impact & cobble, gravel, sand \\
\hline & R4 & 75 & Agriculture impact & cobble, gravel, sand \\
\hline \multirow[t]{4}{*}{ Gadana river } & G1 & 172 & Native forest & Bedrock, boulders, cobble, gravel, sand \\
\hline & G2 & 144 & Native forest & Bedrock, boulders, cobble, gravel, sand \\
\hline & G3 & 81 & Agriculture impact & cobble, gravel, sand \\
\hline & G4 & 69 & Agri./Human impact & cobble, gravel, sand \\
\hline \multirow[t]{4}{*}{ Tamiraparani } & $\mathrm{T} 1$ & 263 & Native forest & Bedrock, boulders, cobble, gravel, sand \\
\hline & T2 & 254 & Native forest & Bedrock, boulders, cobble, gravel, sand \\
\hline & T3 & 108 & Agriculture impact & cobble, gravel, sand \\
\hline & T4 & 105 & Agriculture impact & cobble, gravel, sand \\
\hline \multirow[t]{9}{*}{ Manimuthar } & M1 & 232 & Native forest & Bedrock, boulders, cobble, gravel, sand \\
\hline & M2 & 210 & Native forest & Bedrock, boulders, cobble, gravel, sand \\
\hline & M3 & 74 & Agriculture impact & cobble, gravel, sand \\
\hline & M4 & 68 & Agriculture impact & cobble, gravel, sand \\
\hline & TP1 & 1266 & Tea plantations & Bedrock, sand, mud \\
\hline & TP2 & 1055 & Tea plantations & Boulders, cobble, gravel, sand \\
\hline & TP3 & 1037 & Tea plantations & Cobble, gravel, sand \\
\hline & TP4 & 1011 & Tea plantations & cobble, gravel, sand \\
\hline & TP5 & 998 & Tea plantations & Boulders, cobble, gravel, sand \\
\hline \multirow[t]{4}{*}{ Nambiyar } & $\mathrm{N} 1$ & 669 & Native forest & Bedrock, boulders, cobble, gravel, sand \\
\hline & N2 & 445 & Native forest & Bedrock, boulders, cobble, gravel, sand \\
\hline & N3 & 227 & Agriculture impact & boulders, cobble, gravel, sand \\
\hline & N4 & 182 & Agriculture impact & Boulders, cobble, gravel, sand \\
\hline
\end{tabular}

\section{RESULT}

\section{> PHYSICO-CHEMICAL CHARACTERISTICS OF RIVERS}

The air temperature and water temperature (at the time of sampling) did not differ across two land-use categories (i.e. reference sites and tea plantation sites) but differed at agriculturallyimpacted sites. The $\mathrm{pH}$ and conductivity, alkalinity and hardness differed in the three riparian land-use categories. Dissolved oxygen was higher at reference sites than in the other two land-use categories. Biological oxygen demand (BOD) and chemical oxygen demand (COD) were lower at reference sites and tea plantation sites but higher at agriculturally-impacted sites. Total solids, total dissolved solids and total suspended solids were lower at reference and tea plantation sites compared with agriculturally-impacted sites. However, the riparian zone width and bank vegetation cover within the agriculturally-impacted site category were noticeably different from reference and tea plantation sites. Summary statistics for physicochemical variables are given in Table II.

\section{> SPECIES COLLECTED}

A total of twenty-eight species belonging to twenty-four genera of six families were collected across all the stream and river types sampled. Baetidae and Leptophlebiidae were the most numerous and ubiquitous families, comprising eight genera in each family and eleven 
Table II

Minimum, mean and maximum of physico-chemical values of three riparian land use categories.

\begin{tabular}{|c|c|c|c|c|c|c|c|c|c|}
\hline \multirow{2}{*}{$\begin{array}{l}\text { PHYSICO-CHEMICAL } \\
\text { PARAMETERS }\end{array}$} & \multicolumn{3}{|c|}{$\begin{array}{c}\text { REFERENCE } \\
\text { SITES }\end{array}$} & \multicolumn{3}{|c|}{$\begin{array}{c}\text { TEA PLANTATIONS } \\
\text { SITES }\end{array}$} & \multicolumn{3}{|c|}{$\begin{array}{l}\text { AGRICULTURAL } \\
\text { IMPACT SITES }\end{array}$} \\
\hline & $\overline{M i n}$ & Mean & $\operatorname{Max}$ & Min & Mean & $\overline{\operatorname{Max}}$ & $\overline{\text { Min }}$ & Mean & $\overline{\operatorname{Max}}$ \\
\hline Air temperature $\left({ }^{\circ} \mathrm{C}\right)$ & 25.7 & 29 & 31.9 & 25.9 & 29 & 30.8 & 28.8 & 32.2 & 34.2 \\
\hline Water temperature $\left({ }^{\circ} \mathrm{C}\right)$ & 20.2 & 23 & 31.6 & 20.4 & 23 & 25.7 & 22.4 & 26.7 & 31.4 \\
\hline $\mathrm{pH}$ & 5.7 & 6.7 & 8.4 & 5.9 & 6.8 & 7.9 & 5.2 & 6.9 & 8.4 \\
\hline Conductivity $\left(\mu \mathrm{S} \cdot \mathrm{cm}^{-1}\right)$ & 10 & 17.5 & 35 & 12 & 21.5 & 31 & 13.8 & 26.9 & 50 \\
\hline Alkalinity (mg·L) & 20 & 25 & 40 & 25 & 35 & 40 & 30 & 40 & 50 \\
\hline Hardness $\left(\mathrm{mg} \cdot \mathrm{L}^{-1}\right)$ & 20 & 28 & 40 & 30 & 35 & 40 & 30 & 45 & 60 \\
\hline $\mathrm{DO}\left(\mathrm{mg} \cdot \mathrm{L}^{-1}\right)$ & 6.2 & 7.6 & 8 & 6.5 & 6.9 & 7.5 & 6 & 6.4 & 6.8 \\
\hline $\mathrm{BOD}\left(\mathrm{mg} \cdot \mathrm{L}^{-1}\right)$ & 4 & 6 & 7 & 4.3 & 6.8 & 9.5 & 6.1 & 6.3 & 8 \\
\hline COD $\left(\mathrm{mg} \cdot \mathrm{L}^{-1}\right)$ & 12 & 14 & 18 & 12 & 14 & 16 & 11 & 15.5 & 18 \\
\hline TS $\left(m g \cdot L^{-1}\right)$ & 20 & 25 & 48 & 25 & 25.5 & 40 & 15 & 29.8 & 50 \\
\hline TDS (mg. $\left.\mathrm{L}^{-1}\right)$ & 7.2 & 14.2 & 28 & 10 & 15.7 & 20 & 10 & 18.1 & 30 \\
\hline TSS (mg. $\left.\mathrm{L}^{-1}\right)$ & 12.8 & 17.5 & 20 & 15 & 17.7 & 20 & 5 & 14.6 & 20 \\
\hline
\end{tabular}

Micro Siemens per centimetre $\left(\mu \mathrm{S} \cdot \mathrm{cm}^{-1}\right)$.

and nine species, respectively (Tables III and IV). Baetis conservatus Muller-Liebenau and Hubbard (1985), Chopralla similis Muller-Liebenau (1983), Liebebiella vera Muller-Liebenau (1982), Thalerosphyrus flowersi Venkataraman and Sivaramakrishnan (1987), Choroterpes (Euthraulus) nambiyarensis Kumar, Arunachalam and Sivaramakrishnan (2013), Edmundsula lotica Sivaramakrishnan (1985), Nathanella saraswathiae Sivaramakrishnan, Venkataraman and Balasubramanian (1996), Petersula courtallensis Sivaramakrishnan (1984), Thraulus gopalani Grand and Sivaramakrishnan, (1985), Dudgeodes sp. (2008) and Teloganodes kodai Sartori (2008) were restricted to reference sites. Baetis frequentus Muller-Liebenau and Hubbard (1985), Platybaetis arunachalae Kumar, Sundar and Sivaramakrishnan, 2012, Afronurus kumbakkaraiensis Venkataraman and Sivaramakrishnan (1989), Epeorus petersi Sivaruban, Venkataraman and Sivaramakrishnan (2013), Choroterpes (Euthraulus) nambiyarensis and Petersula courtallensis had the highest mean abundance at reference sites (Figure 2). There were significant declines in the densities of Baetis acceptus Muller-Liebenau and Hubbard (1985), Baetis frequentus, Labiobaetis geminatus Muller-Liebenau and Hubbard (1985), Platybaetis arunachalae, Afronurus kumbakkaraiensis, Epeorus petersi, Indialis badia Peters and Edmunds (1970), Isca purpurea Gillies (1951) and Notophlebia jobi Sivaramakrishnan and Peters (1984) at tea plantation sites compared with reference sites. Indobaetis michaelohubbardi Kumar, Sundar and Sivaramakrishnan (2012) and Labiobaetis pulchellus Muller-Liebenau and Hubbard (1985) occurred in both reference and agriculturally-impacted sites. Cloeon bimaculatum Eaton (1885), Procloeon regularum Muller-Liebenau and Hubbard (1985), Caenis sp. Stephens (1853), Clypeocaenis bisetosa Soldan (1978), Torleya nepalica Allen and Edmunds (1963), and Choroterpes (Euthraulus) alagarensis Dinakaran, Balachandran and Anbalagan (2009) werepresent only at agriculturally-impacted sites, while the other species were either extirpated or were poorly represented at these sites (Figure 2).

\section{> CANONICAL CORRESPONDENCE ANALYSIS}

In order to determine which physico-chemical parameters were associated with mayfly species distribution, Canonical Correspondence Analysis was performed. The agriculturallyimpacted portion of the ordination represented sites with high water temperature, air temperature, biochemical oxygen demand, total solids, total dissolved solids, concentration of hardness, conductivity and alkalinity, and low concentration of dissolved oxygen and total suspended solids. CCA revealed a clear separation of the mayfly assemblages along 


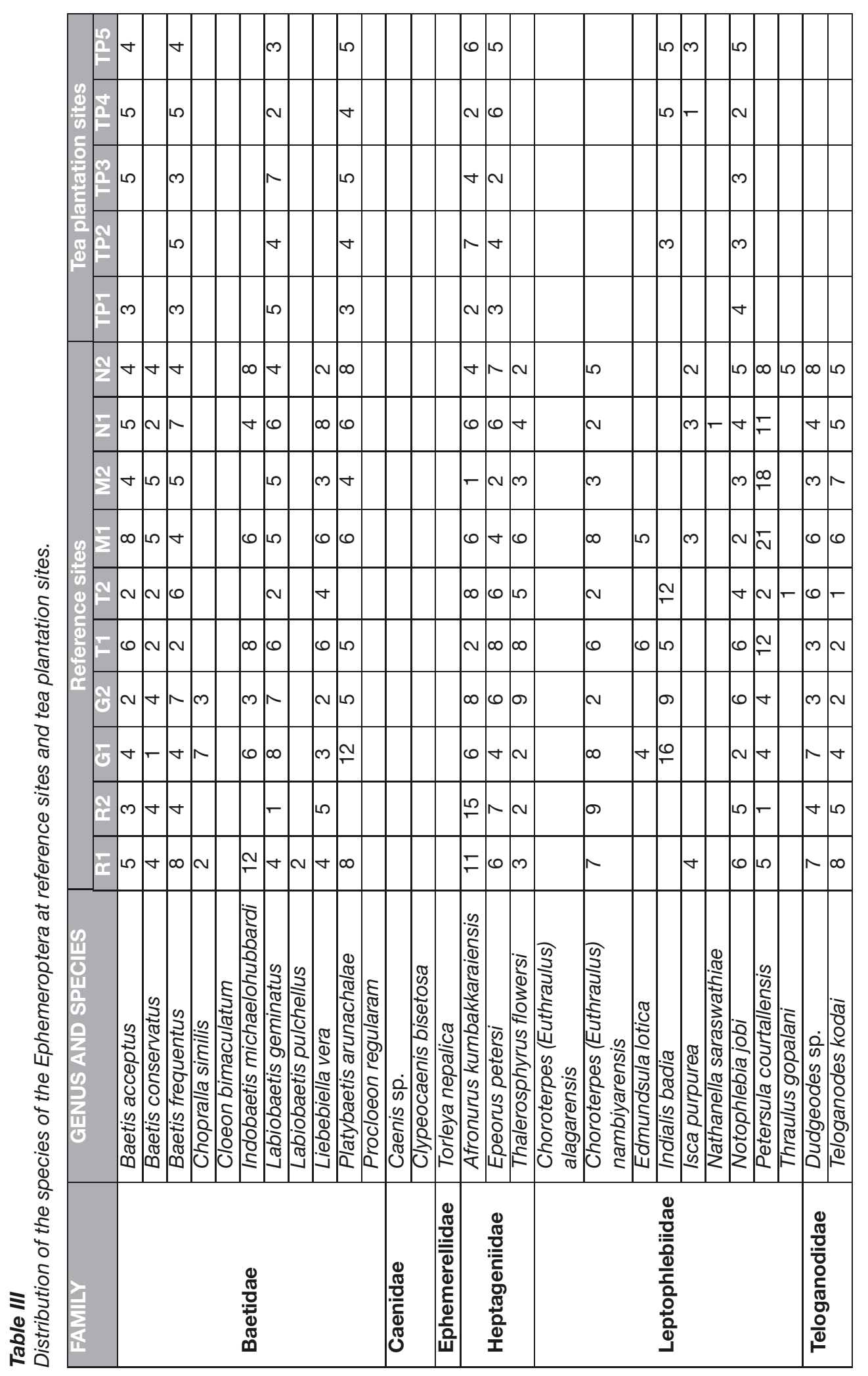


Table IV

Distribution of the species of the Ephemeroptera at agricultural impact sites.

\begin{tabular}{|c|c|c|c|c|c|c|c|c|c|c|c|}
\hline \multirow{2}{*}{ FAMILY } & \multirow{2}{*}{ GENUS AND SPECIES } & \multicolumn{10}{|c|}{ Agricultural impact sites } \\
\hline & & $\mathrm{R3}$ & R4 & $G 3$ & $\mathrm{G} 4$ & T3 & $T 4$ & M3 & M4 & N3 & $\mathrm{N} 4$ \\
\hline \multirow{11}{*}{ Baetidae } & Baetis acceptus & & & & & & & & & & \\
\hline & Baetis conservatus & & & & & & & & & & \\
\hline & Baetis frequentus & & & 6 & 4 & & 4 & & 4 & 2 & \\
\hline & Chopralla similis & & & & & & & & & & \\
\hline & Cloeon bimaculatum & 8 & & 6 & 7 & 8 & 6 & 9 & 5 & 4 & 7 \\
\hline & Indobaetis michaelohubbardi & & & 4 & 8 & 8 & & 4 & & 4 & \\
\hline & Labiobaetis geminatus & 4 & & 8 & 4 & 4 & 9 & 5 & & 5 & 6 \\
\hline & Labiobaetis pulchellus & 4 & & 6 & & 4 & & 6 & & 5 & \\
\hline & Liebebiella vera & & & & & & & & & & \\
\hline & Platybaetis arunachalae & & & & 8 & 6 & & 6 & & 6 & \\
\hline & Procloeon regularam & 6 & 3 & 5 & 4 & 8 & 6 & 3 & 8 & 7 & 5 \\
\hline \multirow[t]{2}{*}{ Caenidae } & Caenis sp. & 6 & 5 & 4 & 5 & 6 & 2 & 7 & 3 & 4 & 3 \\
\hline & Clypeocaenis bisetosa & 2 & 1 & 6 & 3 & 4 & 5 & 4 & 2 & 6 & 5 \\
\hline Ephemerellidae & Torleya nepalica & & & & & 5 & 4 & & & & \\
\hline \multirow[t]{3}{*}{ Heptageniidae } & Afronurus kumbakkaraiensis & & & & & & & & & & \\
\hline & Epeorus petersi & & & & & & & & & & \\
\hline & Thalerosphyrus flowersi & & & & & & & & & & \\
\hline \multirow{9}{*}{ Leptophlebiidae } & $\begin{array}{l}\text { Choroterpes (Euthraulus) } \\
\text { alagarensis }\end{array}$ & 2 & 18 & 3 & 4 & 2 & 4 & & 3 & & 3 \\
\hline & $\begin{array}{l}\text { Choroterpes (Euthraulus) } \\
\text { nambiyarensis }\end{array}$ & & & & & & & & & & \\
\hline & Edmundsula lotica & & & & & & & & & & \\
\hline & Indialis badia & & & & & 7 & 12 & 6 & & 6 & \\
\hline & Isca purpurea & & & & & & & & & & \\
\hline & Nathanella saraswathiae & & & & & & & & & & \\
\hline & Notophlebia jobi & & & & & & & & & & \\
\hline & Petersula courtallensis & & & & & & & & & & \\
\hline & Thraulus gopalani & & & & & & & & & & \\
\hline \multirow[b]{2}{*}{ Teloganodidae } & Dudgeodes sp. & & & & & & & & & & \\
\hline & Teloganodes kodai & & & & & & & & & & \\
\hline
\end{tabular}

water quality and riparian land-use gradients. The occurrence of the Heptageniidae, Leptophlebiidae and Teloganodidae was highly correlated to axes 1 and 2. Caenidae and Ephemerillidae were correlated to axis 3, but Baetidae was correlated to all axes (Figures 3 and 4). At the generic level, Choprella, Liebebiella, Thalerosphyrus, Edmundsula, Nathanella, Petersula, Thraulus, Dudgeodes and Teloganodes were correlated to reference sites. Platybaetis, Afronurus, Epeorus, Isca and Notophlebia were correlated to tea plantation sites. Cloeon, Procloeon, Caenis, Clypeocaenis, Torleya and Choroterpes were highly correlated with agriculturally-impacted sites (Figure 3). Many species, with the exception of Cloeon bimaculatum, Labiobaetis pulchellus, Procloeon regularam, Caenis sp., Clypeocaenis bisetosa, Torleya nepalica and Choroterpes (Euthraulus) alagarensis, which were strongly correlated with agriculturally-impacted sites, were strongly correlated with reference sites with a high percentage of native forest and riparian integrity. Baetis acceptus, Baetis frequentus, Labiobaetis geminatus, Platybaetis arunachalae, Afronurus kumbakkaraiensis, Epeorus petersi, Indialis badia, Isca purpurea and Notophlebia jobi specifically preferred reference sites and tea plantation sites but not agriculturally-impacted sites (Figure 4). This pattern suggests that agricultural activities have a greater degrading impact than forestry conversion. 


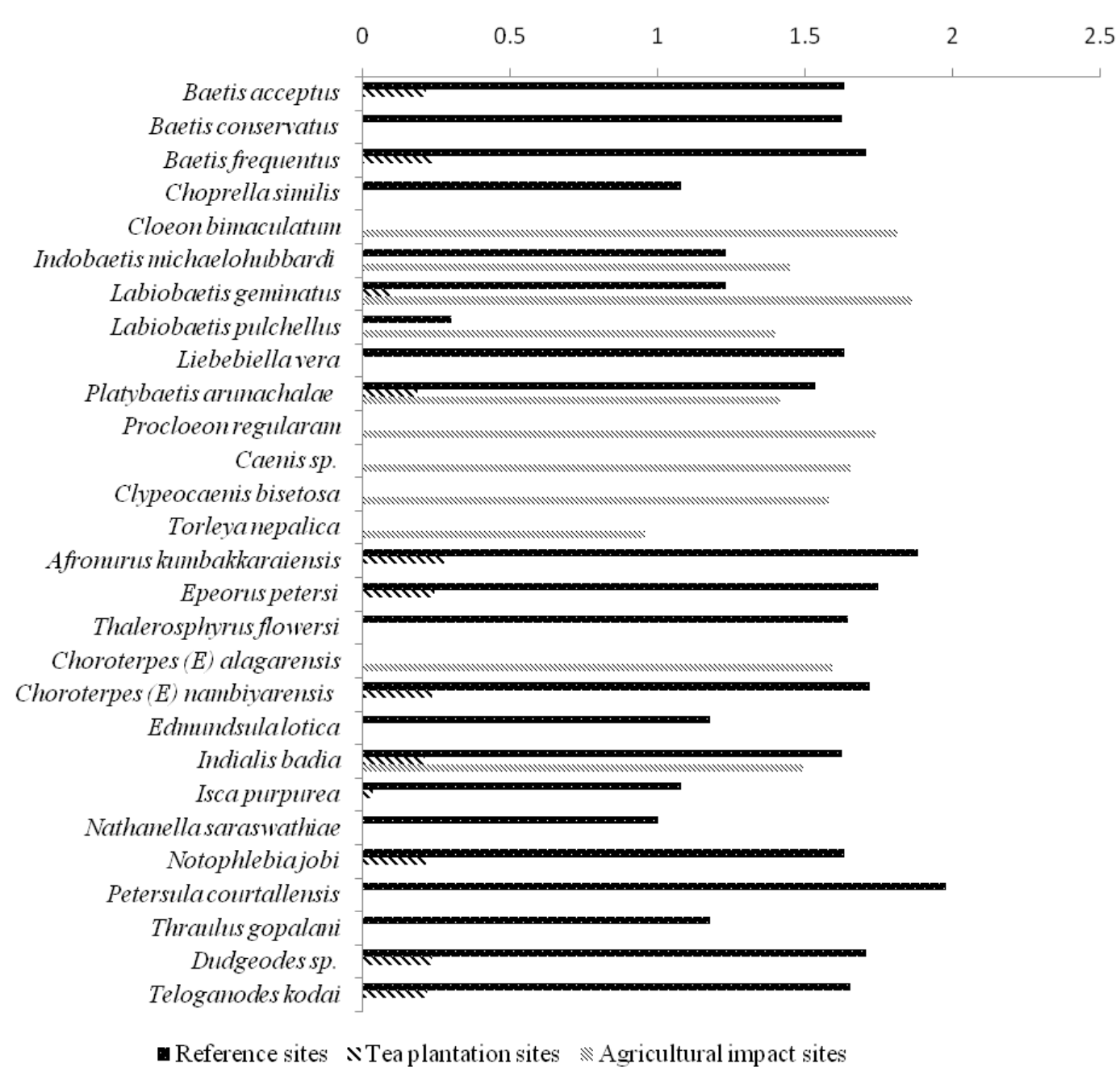

Figure 2

Abundance (log value) of Ephemeroptera species at three riparian land use sites of KMTR.

\section{DISCUSSION}

\section{> STREAM TYPE AND MICROHABITAT QUALITY}

This study highlights the biomonitoring potential and impact of riparian land use in structuring the larval ephemeropteran communities in the riverine systems of the KMTR. The distribution of Baetis conservatus, Chopralla similis, Liebebiella vera, Thalerosphyrus flowersi, Choroterpes (Euthraulus) nambiyarensis, Edmundsula lotica, Nathanella saraswathiae, Petersula courtallensis, Thraulus gopalani, Dudgeodes sp. and Teloganodes kodai was restricted to upstream sites (Figure 2). Streams and rivers of upstream sites are characterised by high altitude, water transparency and higher dissolved oxygen concentration, and low water temperature and turbidity. In contrast, downstream sites are characterised by flow variability, high water temperature, silt load and low altitude. The harsh environmental conditions of downstream sites could have acted as a filter for taxa that are intolerant of low dissolved oxygen concentration and higher water temperatures (Table II). A similar observation was made by Chakona et al. (2009) on caddisfly (Trichoptera) communities of riverine systems of eastern and northwestern Zimbabwe. The following species were mainly distributed in downstream sites: Cloeon bimaculatum, Labiobaetis pulchellus, Procloeon regularam, Torleya nepalica, Caenis sp., Clypeocaenis bisetosa and Choroterpes (Euthraulus) alagarensis. 


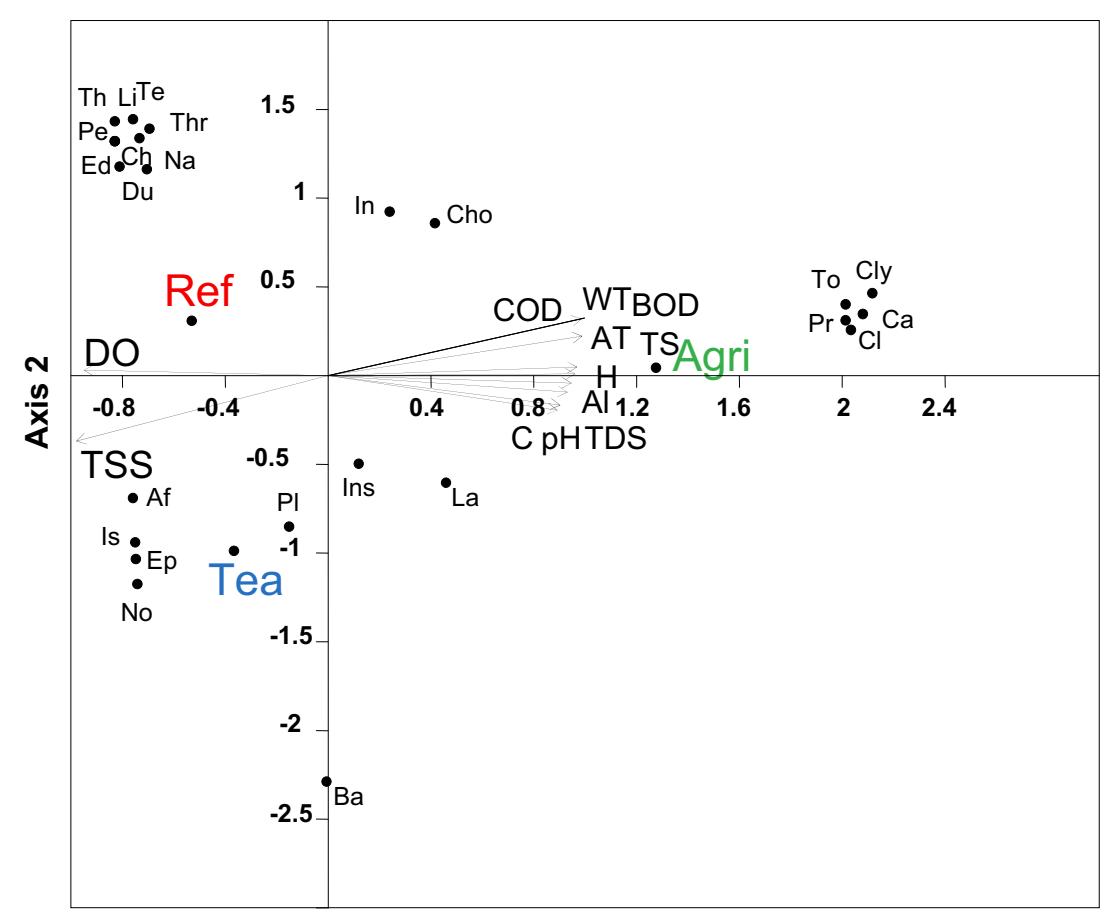

\section{Axis 1}

\section{Figure 3}

Canonical Correspondence Analysis (CCA) based on the Ephemeroptera genera and physico-chemical parameters. Reference sites (Ref): Choprella (Ch); Liebebiella (Li); Thalerosphyrus (Th); Edmundsula (Ed); Nathanella (Na); Petersula (Pe); Thraulus (Thr); Dudgeodes (Du); Teloganode (Te). Tea plantation sites (Tea): Platybaetis (PI); Afronurus (Af); Epeorus (Ep); Isca (Is); Notophlebia (No). Agriculturally impacted sites (Agri): Baetis (Ba); Cloeon (Cl); Indobaetis (In); Labiobaetis (La); Procloeon (Pr); Caenis (Ca); Clypeocaenis (Cly); Torleya (To); Choroterpes (Cho); Indialia (Ins); Air Temperature (AT); Water Temperature (WT); $\mathrm{pH}(\mathrm{pH})$; Conductivity (C); Alkalinity (Al); Hardness (Ha); Dissolved Oxygen (DO); Biological Oxygen Demand (BOD); Chemical Oxygen Demand (COD); Total Solids (TS); Total Dissolved Solids (TDS); Total Suspended Solids (TSS).

\section{> LARVAL EPHEMEROPTERAN COMMUNITY COMPOSITION AND RIPARIAN LAND USE}

The assemblage pattern of mayfly species in a particular site is ultimately determined by the synergistic effects of broad regional factors, altitudinal, latitudinal, stream size and longitudinal gradients along the stream continuum, as well as local physico-chemical factors, habitat heterogeneity and adjoining biotic factors, mainly predator potential. However, the surrounding land-use pattern also in addition to sedimentation inputs within streams exerts an impact in terms of allochthonous food input. The turnover of mayfly species in the streams with different riparian land-use types showed that taxa composition changed with the riparian land use. The assemblage of Ephemeroptera species differed among the riparian land-use categories. There was a trend towards higher species richness and abundance at reference sites and a significant decline in species richness at tea plantation sites. The abundance of Heptageniidae, Leptophlebiidae and Teloganodidae in the reference sites is a result of good water quality and the dominance of native forest along the river banks and within the catchment.

The absence of the Heptageniidae species Thalerosphyrus flowersi, Leptophlebiidae species Choroterpes (Euthraulus) nambiyarensis, Edmundsula lotica and Petersula courtallensis, and Teloganodidae species Dudgeodes sp. and Teloganodes kodai at tea plantation sites may therefore be attributed to replacement of native shrubs and trees with tea plants. Species of Heptageniidae, Leptophlebiidae and Teloganodidae are filter-feeders/scrapers and are known to be important in organic matter breakdown in streams of fallen decaying leaves from adjoining riparian plants. Their absence at deforested agriculturally-impacted sites may 


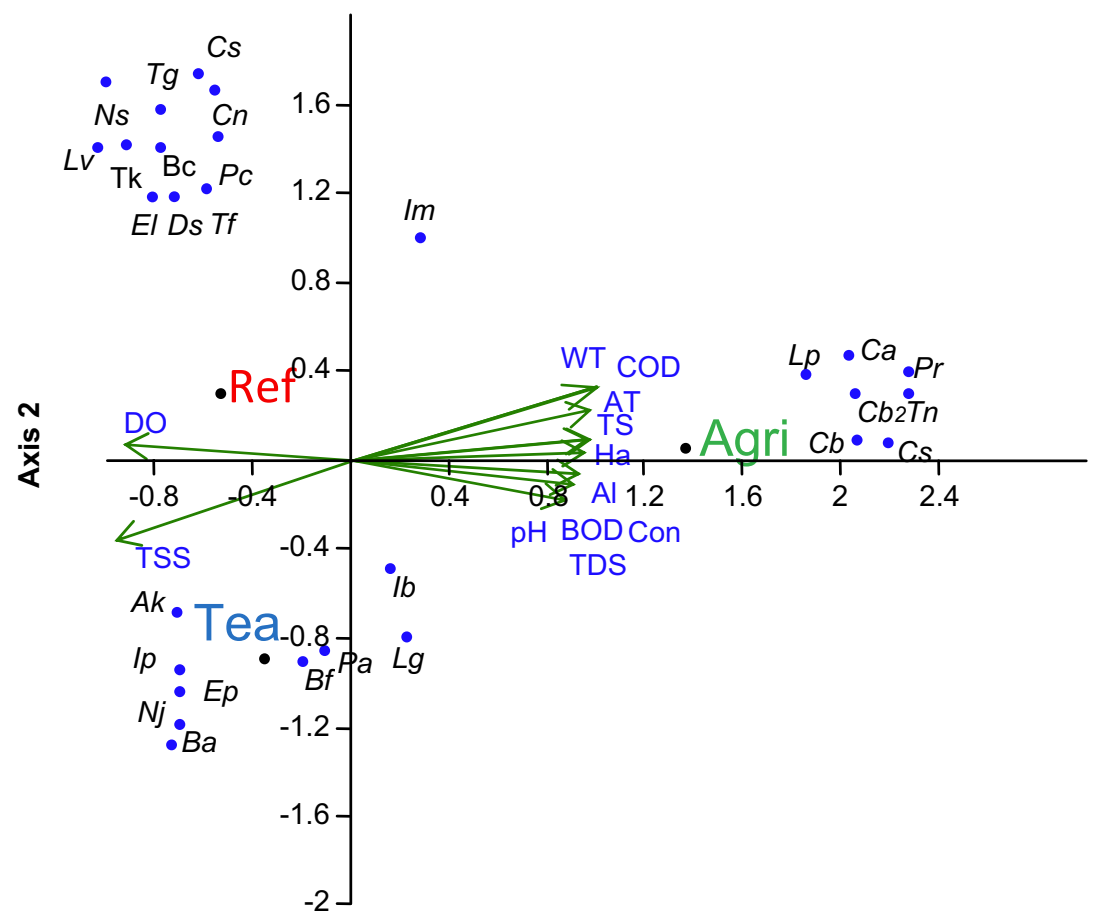

Axis 1

Figure 4

Canonical Correspondence Analysis (CCA) based on the Ephemeroptera species and physico-chemical parameters. Reference sites (Ref): Baetis conservatus (Bc); Baetis frequentus (Bf); Choprella similis (Cs); Liebebiella vera (Lv); Thalerosphyrus flowersi (Tf); Choroterpes (Euthraulus) nambiyarensis (Cn); Edmundsula lotica (El); Nathanella saraswathiae (Ns); Petersula courtallensis (PC); Thraulus gopalani (Tg); Dudgeodes sp. (Ds); Teloganodes kodai (Tk). Tea plantation sites (Tea): Baetis acceptus (Ba); Afronurus kumbakkaraiensis (Ak); Epeorus petersi (Ep); Isca purpurea (Ip); Notophlebia jobi (Nj). Agriculturally impacted sites (Agri): Cloeon bimaculatum (Cb); Indobaetis michaelohubbardi (Im); Labiobaetis geminatus (Lg); Labiobaetis pulchellus (Lp); Platybaetis arunachalae (Pa); Procloeon regularam (Pr); Caenis sp. (Cs); Clypeocaenis bisetosa (Cb); Torleya nepalica (Tn); Choroterpes (Euthraulus) alagarensis (Ca); Indialis badia (lb). Air Temperature (AT); Water Temperature (WT); $p H(p H) ;$ Conductivity (Con); Alkalinity (Al); Hardness (Ha); Dissolved Oxygen (DO); Biological Oxygen Demand (BOD); Chemical Oxygen Demand (COD); Total Solids (TS); Total Dissolved Solids (TDS); Total Suspended Solids (TSS).

be attributed to lack of plant material and an unsuitable habitat and water quality. Landuse parameters that were found to be important descriptors of species distribution patterns were percentage of agricultural land use, percentage of native forest and riparian integrity, as pointed out by Chakona et al. (2009).

The occurrence and abundance of Cloeon bimaculatum, Labiobaetis pulchellus, Procloeon regularam, Torleya nepalica, Caenis sp., Clypeocaenis bisetosa and Choroterpes (Euthraulus) alagarensis at agricultural sites suggest that these species are potential indicators of agricultural impact. A closer look at the distribution of the Ephemeroptera taxa from this study reveals that there were significant declines in species richness and abundance in tea plantation sites. It is quite likely that forest conversion from native to tea plantations might have caused declines in taxa that were recorded from reference sites. Our analysis shows a decrease in species richness and abundance of heptagenids (Afronurus kumbakkaraiensis, Epeorus petersi and Thalerosphyrus flowersi) and lephtophlebids (Choroterpes (Euthraulus) nambiyarensis, Edmundsula lotica, Indialis badia, Notophlebia jobi, Petersula courtallensis and Thraulus gopalani) with decreasing streambed complexity and amount of coarse substrates expressed as percentage of cobbles, percentage of embeddedness and percentage of fine sediments. These mayflies showed a strong preference for a rocky substratum and marginal vegetation, and they use plant material for their food. Heptageniidae, Leptophlebiidae and 
Teloganodidae are filter-feeders/scrapers and they generally preferred a 'clean' cobble substratum for attachment and high to turbulent flow to facilitate filtering (Sivaramakrishnan and Venkataraman, 1987).

The abundance of Cloeon bimaculatum, Labiobaetis geminatus, Labiobaetis pulchellus, Procloeon regularam, Caenis sp., Clypeocaenis bisetosa and Choroterpes (Euthraulus) alagarensis at agriculturally-impacted sites in this study was related to an increase in the percentage of filamentous algae, which are an important food source, as pointed out in previous work (e.g. Sivaramakrishnan and Venkataraman, 1987). Furthermore, their occurrence at silted sites also suggests that these species may be tolerant to increased sedimentation compared with other ephemeropteran taxa collected during this study. The decline in specialist forest taxa and dominance of simplified and/or generalist taxa following removal of riparian vegetation is well documented (Subramanian et al., 2005). This change in community structure is mainly due to changes in the geomorphology and the associated destruction of in-stream physical habitats as a result of increased sedimentation and poor water quality owing to unsustainable landuse practices. Similarly, previous research has documented the negative effects of riparian land-use change (i.e., natural vegetation to agricultural production) on the diversity, richness and distribution of stream insects (Sivaramakrishnan et al., 1996; Subramanian et al., 2005).

\section{> MAYFLY AS BIOINDICATOR TAXA}

With respect to useful bioindicator taxa for measuring riparian land-use impacts in river systems of the study catchments, the results suggest that occurrence of Cloeon bimaculatum, Labiobaetis pulchellus, Procloeon regularam, Torleya nepalica, Caenis sp., Clypeocaenis bisetosa and Choroterpes (Euthraulus) alagarensis belonging to the genera Cloeon, Labiobaetis, Procloeon, Torleya, Caenis and Clypeocaenis may be the best bioindicators ofagricultural impact. The presence of Baetis conservatus, Chopralla similis, Liebebiella vera, Thalerosphyrus flowersi, Choroterpes (Euthraulus) nambiyarensis, Edmundsula lotica, Nathanella saraswathiae, Petersula courtallensis, Thraulus gopalani, Dudgeodes sp. and Teloganodes kodai belonging to Baetis, Chopralla, Liebebiella, Thalerosphyrus, Choroterpes, Edmundsula, Nathanella, Petersula, Thraulus, Dudgeodes and Teloganodes indicate pristine forest conditions with intact riparian vegetation and a high percentage of marginal vegetation.

The Ephemeroptera species Baetis acceptus, Baetis conservatus, Chopralla similis, Liebebiella vera, Afronurus kumbakkaraiensis, Epeorus petersi, Thalerosphyrus flowersi, Choroterpes (Euthraulus) nambiyarensis, Edmundsula lotica, Notophlebia jobi, Petersula courtallensis, Thraulus gopalani, Dudgeodes sp. and Teloganodes kodai were intolerant of fine substrates at agriculturally-impacted sites, and they were reliable indicators of in-stream habitat degradation resulting from increased sedimentation. Overall, the results from this study suggest that Ephemeroptera taxa can be potentially used as reliable bioindicators of organic pollution in running water systems, with biomonitoring potential being progressively more precise when analysed at genus and species levels. However, there is a need for further refined studies by designing experiments to separate land-use change impacts from specific stressors/disturbance to highlight overall synergistic efforts contributing to further deterioration in water quality. However, since many species of these ephemeropteran assemblages are endemic to this ecoregion, the species that are more sensitive to anthropogenic disturbance recorded in this study are particularly relevant to the river catchments of this and adjacent ecoregions and may not be applicable elsewhere in the tropics. Obviously, water quality and riparian land use along with habitat parameters play a significant role in structuring the mayfly assemblages in riverine systems of KMTR.

\section{ACKNOWLEDGEMENTS}

C. Selvakumar would like to thank the University Grants Commission (UGC), New Delhi, India for the award of the Dr. D.S. Kothari Postdoctoral Fellowship [No.F.4-2/2006 (BSR) /13$670 / 2012$ (BSR)]. K.G. Sivaramakrishnan is grateful t the UGC for the award of an Emeritus 
Fellowship [No.F.6-39/2011 (SA-II)] and to Madras Christian College, Chennai, for providing facilities under the Emeritus Fellowship of the UGC. The authors also gratefully acknowledge the Department of Zoology, University of Madras, for providing assistance through the UGC-SAP. The authors sincerely thank the three anonymous referees for their valuable editorial inputs which contributed significantly to refinement of the manuscript.

\section{REFERENCES}

Ahmad A., Maimon A., Othman M.S. and Pauzi M.A., 2002. The potential of local benthic macroinvertebrates as a biological monitoring tool for river water quality assessment. In: Omar R., Ali Rahman Z., Latif M.T., Lihan T. and Adam J.H. (eds.), Proceedings of the Regional Symposium on Environmental and natural Resources, Hotel Renaissance Kuala Lumpur, Malaysia, 464-471.

APHA 1998. Standard method for the examination of water and waste water, American Public Health Association, Inc. New York. 20th Ed., 10-161.

Arimoro F.O. and Muller W.J., 2009. Mayfly (Insecta: Ephemeroptera) community structure as an indicator of the ecological status of a stream in the Niger Delta area of Nigeria. Environmental Monitoring and Assessment, 166, 581-594.

Bae Y.J, Kil H.J. and Bae K.S. 2005. Benthic macroinvertebrates for uses in stream biomonitoring and restoration. KSCE Journal of Civil Engineering, 9, 55-63.

Baptista D.F., Buss D.F., Dorville L.F.M. and Nessimian J.L., 2001. Diversity and habitat preference of aquatic insects along the longitudinal gradient of Macae River basin, Rio de Janeiro, Brazil. Revista Brasileira de Biologia, 61, 249-258.

Bauernfeind E. and Moog O., 2000. Mayflies (Insecta: Ephemeroptera) and the assessment of ecological integrity: A methodological approach. Hydrobiologia, 422-423, 71-83.

Bonada N., Prat N., Resh V.H. and Statzner B., 2006. Developments in Aquatic insect Biomonitoring: A Comparative Analysis of Recent Approaches. Annual Review Entomology, 51, 495-523.

Boonsoong B., Sangpradub N. and Barbour M.T., 2008. Development of rapid bioassessment approaches using benthic macroinvertebrates for Thai streams. Environmental Monitoring and Assessment, 155, 129-147.

Boonsoong B., Sangpradub N., Barbour M.T. and Simachaya W., 2009. An implementation plan for using biological indicators to improve assessment of water quality in Thailand. Environmental Monitoring and Assessment, 165, 205-215.

Burton T.M. and Sivaramakrishnan K.G., 1993. Composition of the insect community in the streams of the Silent valley National park in Southern India. Tropical Ecology, 34, 1-16.

Buss, D.F., 2001. Utilizando macroinvertebrados no desenvolvimento de um procedimento integrado de avaliação da qualidade da água de rios. MS Dissertation. PPGE-UFRJ, Rio de Janeiro. ix + 132p.

Buss D.F. and Salles F.F., 2007. Using Baetidae Species as Biological Indicators of Environmental Degradation in a Brazilian River Basin. Environmental Monitoring and Assessment, 130, 365-372.

Buss D.F., Baptista D.F., Silveira M.P., Nessimian J.L. and Dorvillé L.F.M., 2002. Influence of water chemistry and environmental degradation on macroinvertebrate assemblages in a river basin in southeast Brazil. Hydrobiologia, 481, 125-136.

Cairns J.Jr. Pratt J.R. 1993. A history of biological monitoring using benthic macroinvertebrates. In: Rosenberg D.M. and Resh V.H. (eds.), Freshwater Biomonitoring and Benthic Macroinvertebrates Chapman and Hall New York, 10-27.

Callisto M., Esteves F.A., Gonçalves J.F.Jr. and Fonseca J.J.L., 1998. Benthic macro-invertebrates as indicators of ecological fragility of small rivers ('igarapés') in a bauxite mining region of Brazilian Amazonia. Amazoniana, 15, 1-9.

Chakona A., Phiri C. and Day J.A., 2009. Potential for Trichoptera communities as biological indicators of morphological degradation in riverine systems. Hydrobiologia, 621, 155-167.

De Pauw N., Ghetti P.F., Manzini P. and Spaggiari D.R., 1992. Biological assessment methods for running waters. In: Newman P., Piavaux A. and Sweeting R. (eds.), River water quality-Ecological assessment and control. Commission of European Countries, 11-38. 
Dinakaran S. and Anbalagan S., 2007a. Effects of riparian vegetation on the functional organization of stream communities in southern Western Ghats. J. Aquat. Biol., 22, 25-31.

Dinakaran S. and Anbalagan S., 2007b. Diversity, trophic relationships and biomonitoring potential of Ephemeroptera, Plecoptera and Trichoptera communities in streams of southern Eastern Ghats. Entomon, 32, 169-175.

Dudgeon D., 1994. Research strategies for the conservation and management of tropical Asian streams and rivers. Int. J. Ecol. Environ. Sci., 20, 255-285.

Dudgeon D., 2000. The Ecology of tropical Asian rivers and streams in relation to biodiversity conservation. Annual Review of Ecology and Systematics, 31, 239-263.

Groombridge B and Jenkis M.D., 2000. Global Biodiversity: Earth's living resources in the 21st century. World Conservation Press, Cambridge, UK.

Gupta A. and Michael R.G., 1992. Diversity, distribution and abundance of Ephemeroptera in streams of Meghalaya State, India. Hydrobiologia, 228, 131-139.

Hammer Ø., Harper D.A.T.and Ryan D.D., 2001. PAST: Paleontological Statistics Software Package for Education and Data analysis. Paleontologia Electronica 4, $9 \mathrm{p}$.

Johnsingh A.J.T., 2001. The Kalakad-Mundanthurai Tiger Reserve: A global heritage of biological diversity. Curr. Sci., 80, 378-388.

Kumar C.S, Sundar S. and Arunachalam M., 2012. Diversity and Distribution of Mayflies (Insecta: Ephemeroptera) in Tamirabarani River of Southern Western Ghats, India. Int. J. Appl. Bioresearch, 5, 1-7.

Li L., Zheng B. and Liu L., 2010. Biomonitoring and bioindicators used for river ecosystems: Definitions, approaches and trends. Procedia Environmental Sciences, 2, 1510-1524.

Medina A.I. and Vallania E., 2001. Ephemeroptera: Abundance and distribution in regulated streams (San Luis, Argentina). In: Dominguez E. (ed.), Trends in research in Ephemeroptera \& Plecoptera, The Netherlands: Kluwer Academic, 143-151.

Metcalfe-Smith J.L., 1994. Biological water quality assessment of rivers: use of macroinvertebrate communities. In: Calow P. and Petts G.E. (eds.), The rivers handbook, Blackwell Scientific Publications UK, 144-169.

Muralidharan M., Selvakumar C., Sundar S. and Raja M., 2010. Macroinvertebrates as Potential Indicators of Environmental Quality. Int. J. Biol. Technol., 23-28.

Nelson S.M. and Roline R.A., 2003. Effects of Multiple stressors on the hyporheic invertebrates in a lotic system. Ecol. Indicators, 3, 65-79.

Ogbogu S.S. and Akinya T.O., 2001. Distribution and abundance of insects orders in relation to habitat types in Opa stream reservoir, Nigeria. J. Aquatic Sci., 16, 7-12.

Pond G.J., 2010. Patterns of Ephemeroptera taxa loss in Appalachian headwater streams (Kentucky, USA). Hydrobiologia, 641, 185-201.

Resh V.H., Norris R.H. and Barbour M.T., 1995. Design and implementation of rapid assessment approaches using benthic macroinvertebrates for water resources assessment. Aust. J. Ecol., 20, 108-121.

Rueda J., Camacho A., Mezquita F., Hernanadez R. and Roca J.R., 2002. Effect of episodic and regular sewage discharge on water chemistry and macroinvertebrate fauna of a Mediteranean stream. Water, Air and Soil Pollution, 140, 425-444.

Saunders D.L., Meeuwing J.J. and Vincent A.C.J., 2002. Freshwater protected areas: Strategies for conservation. Conservation Boilogy, 16, 30-41.

Savić , A., Ranđelović V. and Krpo-Ćetković J., 2010. Seasonal variability in community structure, habitat selection of mayflies (Ephemeroptera) in the Nišava River (Serbia). Biotechnol. Biotec. Eq., 24, 639-645.

Savić A., Ranđelović V., Branković S. and Krpo-Ćetković J., 2011. Mayfly (Insecta: Ephemeroptera) community structure as an indicator of the ecological status of the Nišava river (Central Balkan Peninsula). Aquat. Ecosyst. Health Manage., 14, 276-284.

Sharma M.P., Sharma S., Goel V. Sharma P. and Kumar A., 2008. Water quality assessment of Nigland stream using benthic macroinvertebrates. Life Science Journal, 5, 67-72. 
Silveira M.P., Buss D.F., Nessimian J.L., Egler M. and Baptista D.F., 2005. Application of biological measures for stream integrity assessment in South-East Brazil. Environmental Monitoring and Assessment, 101, 117-128.

Sivaramakrishnan K.G., 2000. A refined rapid bioassessment protocol for benthic macroinvertebrates for use in peninsular Indian streams and rivers. In: Ramachandra T.V., Rajasekara Murthy Co. and Ahalya N. (eds.), Proceedings of lake 2000 - Symposium on restoration of Lakes and wetlands. Center for Ecological Sciences, Indian Institute of Science, Bangalore, 302-314.

Sivaramakrishnan K.G. and Venkataraman K., 1987. Observations on feeding properties, growth rate and fecundity in mayflies. Proceedings of Indian Academic Science (Animal Science), 96, 305-309.

Sivaramakrishnan K.G., Morgan H.J. and Vincent R.H., 1996. Biological assessment of the Kaveri river catchment, South India, and using benthic macroinvertebrates: Applicability of water quality monitoring approaches developed in other countries. Int. J. Ecol. Environ. Sci., 32 113-132.

Subramanian K.A., Sivaramakrishnan K.G. and Gadgil M., 2005. Impact of riparian landuse on stream insects of Khudremukh National Park, Karnataka state. India. Journal of Insect Science, 5, 49. 